\title{
Effects of pollutant discharges on the aquatic mammal populations of Terminos Lagoon, Campeche, Mexico
}

\author{
A. Delgado-Estrella, M. del R. Barreto-Castro, \\ G. Acevedo-Olvera \& L. E. Vázquez-Maldonado \\ Facultad de Ciencias Naturales, UNACAR, Campeche, México
}

\begin{abstract}
Terminos Lagoon was made a protected ecosystem by the Mexican government in 1994, but it is also the most important center for oil extraction and transportation companies in the Gulf of Mexico, besides several rivers carrying on city effluents along with agricultural and cattle residuals into the lagoon. The main goal of this study is to analyze the potential for aquatic mammal species such as bottlenose dolphins, manatees and river otters to be environmental sentinels. While data showed that levels of heavy metals and pesticides contained in bottlenose dolphins blubber samples - lead $(<1.1 \mathrm{mg} / \mathrm{l})$ and cadmium $(<0.08 \mathrm{mg} / \mathrm{l})$ - were low, heptachlor epoxies showed the highest values $(359.67 \mu \mathrm{g} / \mathrm{g})$, followed by endosulfan sulfate and methoxychlor,' p-DDE, which was recorded in a sample with concentrations of $239.542 \mu \mathrm{g} / \mathrm{g}$, along with $\mathrm{p}$ 'p-DDD and p' p-DDT, with values of 1.2 and $13.63 \mu \mathrm{g} / \mathrm{g}$, respectively. Analysis of heavy metals in Manatee bones showed that zinc, lead and cadmium presented higher concentrations $(102.60 \pm 27.19 \mu \mathrm{g} / \mathrm{g}, 14.54 \pm 1.77, \mu \mathrm{g} / \mathrm{g}$ and $3.92 \pm 0.5 \mu \mathrm{g} / \mathrm{g}$, respectively). Values of both heavy metals and pesticides in samples were low compared to those recorded in other studies. Water quality analysis at the fluvial-lagoon system POM-Atasta found concentrations of $\mathrm{BOD}_{5}$ of up to $270 \mathrm{mg} / \mathrm{l}, \mathrm{COD} 640 \mathrm{mg} / \mathrm{l}$ and SST $245 \mathrm{mg} / \mathrm{l}$. These environmental and biological parameters, combined with the health assessment results for bottlenose dolphins, indicate that dolphins have a good health condition but human activities such as agriculture, livestock, fishing and boat traffic seem to have a chronic impact on the ecosystem and, subsequently, on the aquatic mammals found in Terminos Lagoon.
\end{abstract}

Keywords: bottlenose dolphins, manatee, pesticides, Terminos Lagoon. 


\section{Introduction}

Terminos Lagoon and its associated wetlands are one of the most important ecological and fishing regions of Mexico. The primary productivity of this ecosystem extends to the adjacent marine ecosystem, and close to $80 \%$ of the fish in the Campeche Sound depends on the lagoon for reproduction and food (Sánchez-Velasco et al. [1]). In terms of biodiversity, Términos Lagoon is one of the most extensive, best conserved and most important wetlands $\left(5,000 \mathrm{~km}^{2}\right)$ in Mexico and in Mesoamerica.

Socio-economic development in Terminos Lagoon has increased considerably in the last few decades due to the growth of the oil industry (Vázquez-Luna [2]). Worldwide, Mexico ranks third place in oil production, first place in offshore oil production, and ninth in crude reserves. Currently, $80 \%$ of its production comes from the Terminos Lagoon region and adjacent marine area. One of the consequences of this increase has been the heavy metal contamination, which anthropogenic input has exceeded natural levels derived from geological processes (Vázquez et al. [3], Sastre Conde et al. [4], Gold-Bouchot et al. [5]). Besides the agricultural activities inland harvesting rice, and sugar cane using a wide variety of chemical pesticides is very important in this region. The seasonal sessions for insect control have been an important source of pesticides in Mexican coastal areas (Albert [6]).

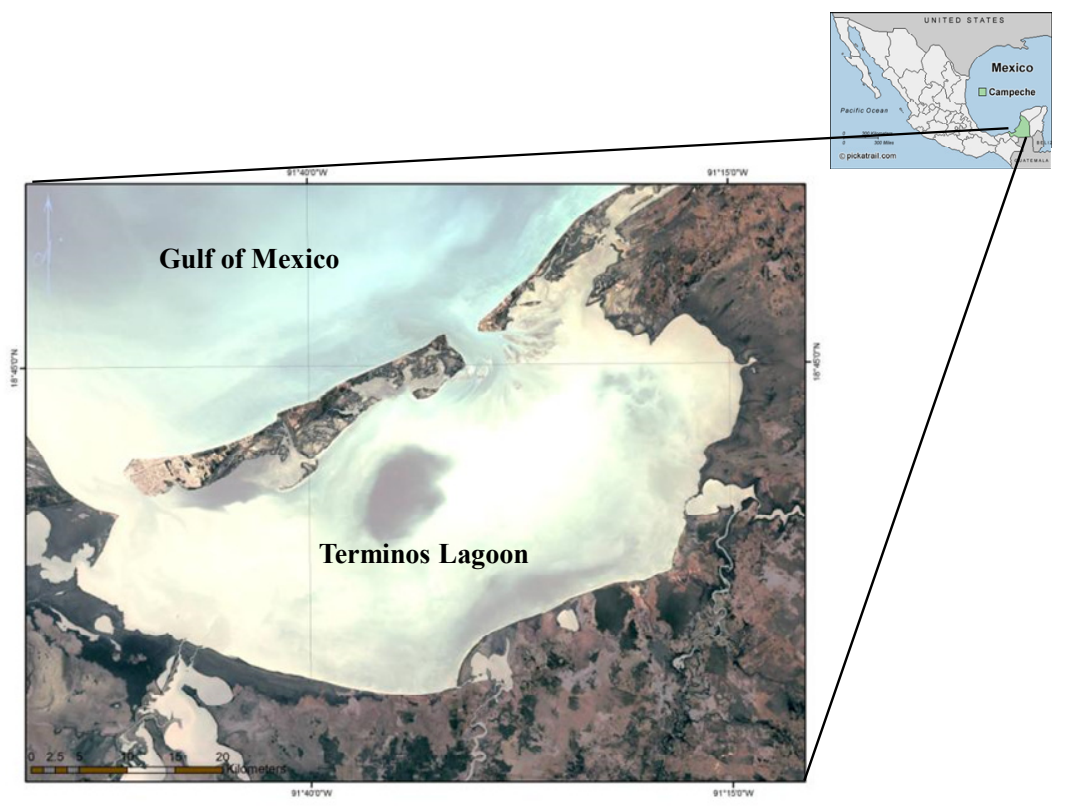

Figure 1: Study area in the Gulf of México. 


\section{Methods}

\subsection{Biological and field sampling}

In order to get samples from live bottlenose dolphins a capture-release program and tissue sampling from stranded dolphins and manatees was developed. All marine mammal species are protected under Mexican law, therefore this study operated with a federal governmental permit. Blubber samples obtained from dolphins and manatees were frozen until the laboratory analysis procedures. Water samples were taken during boat surveys along Terminos Lagoon, stored on ice and analyzed according with de Environmental Mexican regulations NMX (NMX-AA-028-SCFI-2001) for water analyses.

\subsection{Samples analyses}

Dolphin and manatee blubber samples were kept frozen until analysis. These samples were later processed according to EPA 3051 method.

Manatee bone samples were analyzed following metal determination by wet digestion procedures (Helrich [7]). Atomic absorption spectrophotometer (PerkinElmer, model Analyst 3110 and 100) was used with air-acetylene flame and hydrides generation. Calibration was performed with each element's standards of. Blank replicate, calibration curves and reference material from the National Institute of Standards and Technology (NIST) were used to verify the accuracy of the procedure.

\section{Results and discussion}

\subsection{Dolphin samples}

The content of heavy metals in bottlenose dolphins blubber samples were as follows: lead $(<1.1 \mathrm{mg} / \mathrm{l})$ and cadmium $(<0.08 \mathrm{mg} / \mathrm{l})$ were low, while heptachlor epoxies showed the highest values $(359.67 \mu \mathrm{g} / \mathrm{g})$, followed by endosulfan sulfate and methoxychlor,' p-DDE was recorded in a sample with concentrations of $239.542 \mu \mathrm{g} / \mathrm{g}$, along with $\mathrm{p}$ 'p-DDD and p' p-DDT with values of 1.2 and $13.63 \mu \mathrm{g} / \mathrm{g}$ respectively (table 1 ).

\subsection{Heavy metals contents in Manatee bone samples}

Analysis of heavy metals in Manatee bones shows that zinc, lead and cadmium presented higher concentrations $(102.60 \pm 27.19 \mu \mathrm{g} / \mathrm{g}, 14.54 \pm 1.77, \mu \mathrm{g} / \mathrm{g}$ and $3.92 \pm 0.5 \mu \mathrm{g} / \mathrm{g}$ respectively) (Romero-Calderón et al. [8]). Values of both heavy metals and pesticides in biopsies were low compared to those recorded in other studies. Analyses of heavy metals in Manatee bones shows that zinc, lead and cadmium presented higher concentrations $(102.60 \pm 27.19 \mu \mathrm{g} / \mathrm{g}, 14.54 \pm$ $1.77 \mu \mathrm{g} / \mathrm{g}$ and $3.92 \pm 0.5 \mu \mathrm{g} / \mathrm{g}$, respectively) (Romero-Calderón et al. [8]). Values of both heavy metals and pesticides in biopsies were low compared to those recorded in other studies. 
Table 1: Pesticides values in bottlenose dolphin blubber samples collected during 2010-2011.

\begin{tabular}{|c|c|c|}
\hline Sample & Chemical compound & Concentration $(\mu \mathrm{g} / \mathrm{g})$ \\
\hline \multirow[t]{2}{*}{ Dolphin 1} & Epoxide Heptachlor & 359.672 \\
\hline & Metoxichlor & 22.891 \\
\hline \multirow[t]{5}{*}{ Dolphin 2} & Endosulfan 11 (b) & 16.260 \\
\hline & Endrin Ketone & 16.786 \\
\hline & Epoxide de Heptachlor & 287.993 \\
\hline & Gama HCH & 8.241 \\
\hline & pp DDT & 13.637 \\
\hline \multirow[t]{7}{*}{ Dolphin 3} & Endosulfan 11 (b) & 27.390 \\
\hline & Endosulfan Sulfate & 37.290 \\
\hline & Endrin Ketone & 19.512 \\
\hline & Epoxide Heptachlor & 174.553 \\
\hline & Gama HCH & 13.818 \\
\hline & Heptachlor & 12.568 \\
\hline & Metoxichlor & 52.580 \\
\hline \multirow[t]{3}{*}{ Dolphin 4} & Dieldrin & 64.172 \\
\hline & Endrin Ketone & 16.643 \\
\hline & Epoxide de Heptachlor & 275.322 \\
\hline \multirow[t]{2}{*}{ Dolphin 11} & Dieldrin & 2.353 \\
\hline & Pp DDT & 1.441 \\
\hline \multirow{5}{*}{ Dolphin 12} & Endosulfan Sulfate & 3.052 \\
\hline & Endrin & 0.803 \\
\hline & Dieldrin & 0.696 \\
\hline & Endosulfan I (a) & 0.855 \\
\hline & pp DDE & 1.401 \\
\hline \multirow[t]{3}{*}{ Dolphin 13} & Endosulfan Sulfate & 20.628 \\
\hline & Beta $\mathrm{HCH}$ & 44.984 \\
\hline & pp DDE & 22.725 \\
\hline Dolphin 14 & Pp DDT & 16.681 \\
\hline \multirow[t]{6}{*}{ Dolphin 15} & Delta $\mathrm{HCH}$ & 13.778 \\
\hline & pp DDE & 1.633 \\
\hline & Endosulfan Sulfate & 4.614 \\
\hline & Endrin aldehyde & 3.835 \\
\hline & Heptachlor & 1.108 \\
\hline & Metoxichlor & 17.764 \\
\hline \multirow[t]{4}{*}{ Dolphin 16} & Delta HCH & 57.977 \\
\hline & Aldrin & 0.668 \\
\hline & Endosulfan I (a) & 1.106 \\
\hline & Endosulfan II (b) & 2.065 \\
\hline
\end{tabular}


Table 2: $\quad$ Heavy metals values $(\mu \mathrm{g} / \mathrm{g})$ in Trichechus manatus manatus bone samples found in Campeche, México.

\begin{tabular}{|c|c|c|c|c|c|c|c|}
\hline Locality & Sex & $\mathbf{C d}$ & $\mathbf{C r}$ & $\mathbf{C u}$ & $\mathbf{P b}$ & $\mathbf{N i}$ & $\mathbf{Z n}$ \\
\hline Campeche & $\mathrm{M}$ & 3.528 & 8.844 & 3.878 & 12.767 & 9.206 & 77.414 \\
\hline Campeche & $\mathrm{M}$ & 3.569 & 6.850 & 3.473 & 13.337 & 8.196 & 81.418 \\
\hline Campeche & $\mathrm{M}$ & 4.608 & 8.024 & 4.068 & 15.622 & 9.601 & 120.367 \\
\hline Campeche & $\mathrm{I}$ & 3.967 & 10.012 & 4.114 & 16.453 & 10.265 & 131.220 \\
\hline Mean & & 3.918 & 8.432 & 3.883 & 14.545 & 9.317 & 102.605 \\
\hline Std. Dev. & & 0.501 & 1.334 & 0.292 & 1.772 & 0.866 & 27.189 \\
\hline
\end{tabular}

In the Terminos Lagoon area, high Cadmium has not been found in fish and sea turtles egg samples, but in shrimp, bottlenose dolphins (blubber) and manatee (blubber) the mean concentrations were 0.1027, 0.3069 and $0.0159 \mathrm{ppm}$, respectively (Benítez et al. [9]). Delgado-Estrella et al. [10] reported low levels in cadmium and no traces of lead, however zinc concentrations were very high.

Benítez et al. [9] reported that cadmium, lead and chrome highest levels were found in sediments and some crustaceans near Ciudad del Carmen, Campeche when they performed a heavy metals spatial analysis at the Terminos Lagoon, suggesting an anthropogenic source for these pollutants.

The concentrations in all metals in bone tissues were predominantly higher, compared with distinct types of bones in other aquatic mammal species around the world.

Differences were found in metal concentrations of manatees between the two regions Caribbean and Gulf of México. In the x Gulf of Mexico group, $\mathrm{Cr}, \mathrm{Cu}, \mathrm{Zn}$ and $\mathrm{Pb}$ showed higher concentrations. The use and production of fertilizers and pesticides, domestic effluents and production of oil in this region (Páez-Osuna et al. [11]) could be the main source of these metals. Earlier studies have shown higher concentrations of $\mathrm{Pb}$ in fish, shrimp and crocodiles of the Gulf of Mexico (Vázquez et al. [12], Trillanes et al. [13]).

\subsection{Water samples}

Water quality analysis at fluvial-lagoon system POM-Atasta found concentrations of $\mathrm{BOD}_{5}$ up to $270 \mathrm{mg} / \mathrm{l}$, COD $640 \mathrm{mg} / \mathrm{l}$ and SST $245 \mathrm{mg} / \mathrm{l}$, these high concentrations can be explained as the area is located next to the industrial fishing port and the river flows. This area is a coastal system that has high influence by tides and fluvial stream conditions because the presence of many small and medium cities along the river basin.

\section{Conclusions}

With these results, it is clear that the long-term effects of pesticides and heavy metals are reflected in aquatic mammals inhabiting Terminos Lagoon. For this reason, the continuous monitoring of these species is vital to understanding the historical and current adverse effects of human activities in the region, which is 
considered to be an area of great environmental importance for the conservation of the Southern Gulf of Mexico flora and fauna. The deterioration of dolphins and manatees habitat conditions for reflects the degree of conservation of natural resources which can be used as a tool for the conservation of wetlands.

\section{Acknowledgements}

We wish to thank to the PROFOCIE 2014 for financially supporting the production and presentation of this paper. Our thanks to Valentina Islas for the translation assistance.

\section{References}

[1] Sánchez-Velasco L., C. Flores-Coto \& B. Shirasago., Fish Larvae Abundance and Distribution in the Coastal Zone off Terminos Lagoon, Campeche (Southern Gulf of Mexico). Estuarine, Coastal and Shelf Science, 43 (6), pp. 707-721, 1996.

[2] Vázquez-Luna D., Environmental Bases on the Exploitation of Crude Oil in Mexico (chapter 5). Crude Oil Exploration in the World, ed. M. Abdel-Aziz. ISBN: 9535103790, pp. 89-106, 2012.

[3] Vázquez F.G., V.K. Sharma \& L. Pérez-Cruz., Concentrations of elements and metals in sediments of the southeastern Gulf of Mexico. Environmental Geology, 42, pp. 41-46, 2002.

[4] Sastre Conde I., Z.E. Reyes-Fernández, R.C. Cancino-Contreras, L. RejónLorenzo, M.E. Santoyo-Velázquez, M.Y. Sabido-Pérez, A. Ruiz-Marín, \& J.A. González-Oreja, Heavy metal distribution in the sediments of the fluvial-lagoon system Pom-Atasta, Campeche (Mexico). Proc. of the 2nd International Conference on Remediation of Contaminated Sediments, eds. M. Pellei \& A. Porta, Venice, Italy, 2003.

[5] Gold-Bouchot G., O. Zapata-Perez, V. Ceja-Moreno, G- RodriguezFuentes, R. Sima-Alvarez, M. L. Aguirre-Macedo \& V. M. Vidal-Martinez., Biological effects of environmental pollutants in American Oyster, Crassostrea virginica: a field study in Laguna de Terminos, Mexico. International Journal of Environment and Health, 1(2), pp. 171-184, 2007.

[6] Albert, L.A. Uso de plaguicidas en las zonas costeras del Golfo de México e investigación sobre su impacto. Golfo de México. Contaminación e impacto ambiental: diagnostico y tendencias. ed. Botello, J. Rendon von Osten, J.A. Benpitez y G. Gold-Bouchot UAC, UNAM-ICML, CINVESTAV-Unidad Mérida, pp. 265-284. 2014.

[7] Helrich, K. Official Methods of Analysis, $15^{\text {th }}$ ed., Association of Official Analytical Chemists, Inc., Airlington, VA, USA, p. 84, 1990.

[8] Romero-Calderón, A.G., B. Morales-Vela, R. Rosíles-Martínez, L.D. Olivera-Gómez, \& A. Delgado-Estrella” Metals in bone tissue of manatees from the Gulf of México and Chetumal Bay, Mexico. In Press.

[9] Benítez, J.A., J. Vidal., T. Brichieri-Colombi, \& A. Delgado-Estrella. Monitoring ecosystem health of the Terminos Lagoon region using heavy 
metals as environmental indicators, pp. 349-358, eds C.A. Brebbia \& T-S. Chon. WIT Transactions on Ecology and The Environment, Vol. 162. WitPress, 2012.

[10] Delgado-Estrella, A., G. Rivas-Hernández., M.R. Barreto-Castro \& G. Acevedo-Olvera. Determinación de metales pesados en biopsias de toninas colectadas en la región de la laguna de Términos, Campeche, México, pp. 580-591, eds Alfonso Vázquez Botello, Jaime Rendón Von Osten, Jorge A. Benítez Torres y Gerardo Gold Bouchot. "Golfo de México, Contaminación e Impacto Ambiental: Diagnóstico y Tendencias", UAC, UNAM-ICMyL CINVESTAV/IPN Unidad Mérida. 1174 pp. ISBN: 978607-7887-71-3. México, 2014.

[11] Páez-Osuna, F., Fuentes de Metales en la Zona Costera Marina. ed, Botello A V, Rendón-Von Osten J, Gold-Bouchot G, Agraz-Hernández C Golf. México Contam. E Impacto Ambient. Diagnóstico y Tendencias, 2nd ed. Univ. Autón. De Campeche, Univ. Nal. Autón. De México, Instituto Nacional de Ecología, Campeche, pp. 329-342, 2005.

[12] Vázquez F.G., Sharma V.K., Mendoza Q.A., \& Hernandez R., Metals in fish and shrimp of the Campeche sound, Gulf of Mexico. Bull. Environ. Contam. Toxicol., 67: 756-762, 2001.

[13] Trillanes C.E., J.C. Pérez-Jiménez, R. Rosíles-Marínez \& M. GonzálezJáuregui. Metals in the Caudal Scutes of Morelet's Crocodile (Crocodylus moreletii) from the Southern Gulf of Mexico. Bull. Environ. Contam. Toxicol., DOI: 10.1007/s00128-014-1349-8, 2014. 